\title{
IBM research to stress products and results
}

Washington. As International Business Machines (IBM) Corporation fights to reverse one of the worst corporate declines in financial history, its \$6.6-billion research programme is shrinking and changing direction. A cut of $\$ 1$ billion in the overall programme, most of which goes into product development, is being accompanied by a shift towards product-related work and reduced support for risky outside ventures.

IBM, the world's largest computer manufacturer, had an abysmal year in 1992. The share price of its stock dropped by half, it lost $\$ 5$ billion and, for the first time ever, it laid off an estimated 25,000 people in a work force of 300,000 . James McGroddy, head of IBM research, says his division will be hiring fewer scientists and engineers and that the work force of 3,300 people at IBM's three research centres in New York, California and Switzerland will shrink this year, from attrition, by "a couple of per cent".

The company's research division, which has sponsored Nobel prize-winning basic research in atomic physics, materials science and other fields along with its more product-related research, spent about $\$ 650$ million last year. Although that figure will drop by as much as ten per cent this year, McGroddy says that most scientists will still have what they need. "We're coming from a background where we've lived pretty well", he says.

What will change is the way in which the money is spent. In recent years, IBM has shifted from basic science and technology towards work that is more customer-orientated, what McGroddy calls "services, applications and solutions". Such work accounts for about five per cent of the research division's current activities, but McGroddy expects it to reach 20 per cent by the end of 1994.

Although IBM is reducing its support for semiconductor technology and related sciences, the change "doesn't mean there is no opportunity for physicists", says McGroddy. But they may wind up doing something other than physics, he says.

The changes at IBM are the latest example of an ailing high-technology company trying to tie its research programme more directly to the bottom line. Frank Nayadas of the Sloan Foundation, a former IBM vice president, says, "What IBM will have to do is focus its research in the businesses it expects to be in", even if that means a shift away from hard sciences and towards such areas as software and algorithm development. But McGroddy welcomes that shift. "The research lab is not a national monument you don't ever want to change", he says.

IBM's problems are also likely to mean the end of support for unprofitable outside ventures. This new attitude has already claimed one victim, supercomputer designer Steve Chen, whose Supercomputing Systems Inc. (SSI) of Eau Claire, Wisconsin, closed its doors on 25 January after IBM, its dwindling for vector processors of the kind Chen was building. "I'm not sure his machine is what the world needs", says Curt Rohrman, a Wall Street analyst with First Boston Corporation. In fact, IBM was this week expected to introduce a different kind of supercomputer, a massively parallel processor based on years of in-house research.

IBM may also become more stingy with its funding of university research. The research division spends $\$ 4$ million a year supporting university research in areas of interest to the company, and other divisions have similar arrangements. Ettore Infante, a vice president for academic affairs for the University of Minnesota system, which now gets $\$ 700,000$ a year from IBM, expects some programmes to suffer as a result of the retrenchment.

University researchers may also be affected if, as expected, IBM becomes more aggressive in seeking funding from the US government. The Navy, for example, has funded IBM laser scientists, and the company belongs to a consorment in the small company, which was attempting to build the world's fastest supercomputer. IBM is said to have spent more than $\$ 100$ million on SSI before it decided that the company would never make the grade.

"[Chen's] machine was a very beautiful design", says Malvin Kalos, director of the Cornell Theory Centre. "It could have been extraordinary if it had come to market very early." But Chen had worked on the new supercomputer for five years with nothing to show for it, and was believed to need another two years.

Even if he had succeeded, the market is tium of companies working on superconductors with money from the Pentagon's Defense Advanced Research Projects Agency. Federal grants make up only a tiny part of the company's total research budget, says IBM spokesman Denis Arvay, but any increase would be felt by academic scientists competing for the same funds.

IBM insists that its commitment to basic research will remain strong, but acknowledges that its future is uncertain. The motto of the research division is to be both "famous for its science and technology" and "vital to IBM", says McGroddy, but it appears that the latter has now taken on greater importance.

Tony Reichhardt

\section{Cray's Rollwagen gets Commerce job}

Washington. John Rollwagen, chairman of Cray Research, Inc., has been nominated by US President Bill Clinton for the number two job at the Department of Commerce under Ron Brown. As head of the world's largest seller of supercomputers, Rollwagen adds the technological and business experience that Brown lacks to a department that Clinton wants to figure prominently in his programme of economic stimulation.

Rollwagen, CEO of Cray since 1980, is expected to be a popular choice among high-technology industrialists. Charles
Larson of the Industrial Research Institute says he "certainly understands the technology and the problems of commercializing technology". Rollwagen is currently a member of the presidential Advisory Committee for Trade Negotiations.

Rollwagen talks regularly with Vice President Al Gore about high-technology issues, and last summer Gore made a campaign visit to Cray's headquarters outside Minneapolis. Gore is well known for his interest in creating a national "information infrastructure".

Tony Reichhardt 